\title{
Effectiveness of planned health education on knowledge of nurses working at tertiary care hospital regarding early detection of cancer cervix Karad, Western Maharashtra, India
}

\author{
Sunita Tata ${ }^{1 *}$, Radhika Joshi ${ }^{2}$, A. Pratinidhi ${ }^{3}$, Vaishali Vhaval ${ }^{2}$, Simi Elsa Philip ${ }^{4}$, \\ Rabnna I. Mulla ${ }^{5}$, S. Kakade ${ }^{5}$
}

\author{
${ }^{1}$ Department of Nursing, KH, KIMSDU, Karad, Maharashtra, India \\ ${ }^{2}$ Department of Obstetrics and Gynecology, KH, KIMSDU, Karad, Maharashtra, India \\ ${ }^{3}$ Department of Research, KH, KIMSDU, Karad, Maharashtra, India \\ ${ }^{4}$ Department of Nursing, KH, KIMSDU, Karad, Maharashtra, India \\ ${ }^{5}$ Statistician, KH, KIMSDU, Karad, Maharashtra, India
}

Received: 22 September 2017

Revised: 09 October 2017

Accepted: 23 November 2017

\section{*Correspondence:}

Dr. Sunita Tata,

E-mail: nursingdirector@kimsuniversity.in

Copyright: () the author(s), publisher and licensee Medip Academy. This is an open-access article distributed under the terms of the Creative Commons Attribution Non-Commercial License, which permits unrestricted non-commercial

\begin{abstract}
Background: Cervical cancer is a major and devastating cause of mortality worldwide with an estimated global incidence of 5 lakhs new cases and 2.7 lakhs deaths annually among women. The objective of this study was to assess the existing level of knowledge and to determine the effectiveness of planned health education among the nurses regarding early detection and prevention of ca cervix.

Methods: Evaluative approach with Quasi experimental one group pre-test-post-test design was used.168 sample were selected with simple random sampling technique, who those are working in tertiary care hospital, Karad. A pretest given related to cervical cancer questionnaires followed by planned health education imparted for the duration of 45 minutes. Post-test using the same questionnaire were conducted after 7 days.

Results: The study results showed that, the planned health education was effective in increasing the knowledge at the level of $\mathrm{P}<0.001$.

Conclusions: It is seen that training of nurses less than 30 years, even with lesser experience lesser than 5 years and with unmarried status benefited most. In service education training at the time of induction program and also frequently to refresh to sensitize the nurses with updating knowledge is recommended so that they can motivate the symptomatic and asymptomatic women who those are attending hospital as an outdoor patient or coming with the indoor patient as caretakers.
\end{abstract}

Keywords: Cervical cancer, Effectiveness, Knowledge, Planned health education, Prevention

\section{INTRODUCTION}

Cervical cancer is a cancer arising from the cervix. It is due to the abnormal growth of cells that have the ability to invade or spread to other parts of the body. Early on, typically no symptoms are seen. Later symptoms may include abnormal vaginal bleeding, pelvic pain, or pain during sexual intercourse. ${ }^{1}$

The World has a population of 2,784 million women aged 15 years and older who are at risk of developing cervical cancer. Current estimates indicate that every year 
527,624 women are diagnosed with cervical cancer and 265,672 dies from the disease. Cervical cancer ranks as the fourth most frequent cancer among women in the world. ${ }^{2}$ India has a population of 432.2 million women aged 15 years and older who are at risk of developing cancer. Every year in India, 122,844 women are diagnosed with cervical cancer and 67,477 dies from the disease. It is the second most common cancer in women between 15 to 45 years of age and the third most common cause of cancer related mortality in women. ${ }^{3}$

Early detection of cancer greatly increases the chances for successful treatment. There are two major components of early detection of cancer: education to promote early diagnosis and screening. Recognizing possible warning signs of cancer and taking prompt action leads to early diagnosis. Increased awareness of possible warning signs of cancer, among physicians, nurses and other health care providers as well as among the general public, can have a great impact on the disease. Some early signs of cancer include lumps, sores that fail to heal, abnormal bleeding, persistent indigestion, and chronic hoarseness. Early diagnosis is particularly relevant for cancers of the breast, cervix, mouth, larynx, colon and rectum, and skin. ${ }^{4}$

The best way to find cervical cancer early is to have regular screening with a Pap test (which may be combined with a test for human papilloma virus or HPV). As Pap testing became routine in this country, finding pre-invasive lesions (pre-cancers) of the cervix became far more common than finding invasive cancer.

Being alert to any signs and symptoms of cervical cancer can also help avoid unnecessary delays in diagnosis. Early detection greatly improves the chances of successful treatment and can prevent any early cervical cell changes from becoming cancerous. ${ }^{5}$

So, the investigator felt if the bedside nurses from tertiary care hospital has prepared with enough knowledge about particularly early diagnosis and prevention of cancer cervix, they will create awareness while caring women patients of all indoor, outdoor department.

Also, will help in motivating for undergoing screening test, this way it will be helpful in preventing cancer cervix mortality rate in some extent. Also, nurses will become more conscious about own health and concern about their female family members, female health care team and friends too.

\section{METHODS}

In this study a quasi-experimental one group pre-testpost-test design was adopted. Nurses working in tertiary care Hospital Karad were the population and total 8samples were selected by simple random sampling technique for the study.

\section{Inclusion criteria}

Nurses who have completed ANM, GNM, PBSC, BSC Nursing courses and nurses working at Krishna hospital Karad and those who are willing to participate in the study.

\section{Exclusion criteria}

Nurses those were not available during data collection time.

\section{Development of tool}

In the study tool socio-demographic data and a structured knowledge questionnaire prepared. A planned health teaching plan was prepared on the topic of cancer cervix. In the questionnaires demographic data consist of 6 items which were regarding participants age, educational qualification; marital status and year of work experience. The structured knowledge questionnaire had 30 objective items that covered the content areas on general information and meaning of cervical cancer, risk factors and causes, signs and symptoms, preventive measures, screening and treatment. Each item was awarded score 1' for the correct response and 0' for the wrong response.

After taking ethical committees permission and consent from subjects the present study was conducted to find out the effectiveness of planed health education on knowledge of nurses working at tertiary care hospital regarding early detection of cancer cervix.

Questionnaires were validated and modified as per expert's suggestion. Pre-test was conducted on all nurses followed by health education imparted by expert gynaecologist for 45 minutes and also clarified their doubts. After 7 days post-test was given with same questionnaires and data analyzed.

\section{RESULTS}

Among 168, maximum nurses 118 (70.2\%) of them are in the age group of $<30$ years, $19(11.3 \%)$ are in the age group of $40-50$ years, followed by $15(8.9 \%)$ are in the age group of 30-40 years and minimum nurses $16(9.5 \%)$ are in the age group $\geq 50$ years. Majority nurses 97 $(57.7 \%)$ of them are married and $71(42.3 \%)$ nurses are unmarried.

In accordance with qualification, among 168, maximum nurses 96 (57.1\%) were GNM, 44 (26.2\%) were having education BSc, followed by $18(10.7 \%)$ were PBSC and $10(6 \%)$ nurses were having education ANM. In regarding to year of work experience among 168 maximum nurses of $97(57.7 \%)$ having year of work experience between 1-5 years, $37(22 \%)$ were having work experience $\geq 10$ years, $26(15.5 \%)$ were having work experience $<1$ year and minimum nurses $8(4.8 \%)$ were having work experience 5-10 years. 
Table 1: Comparison of means and standard deviation between pre-test and post-test level of nurses' knowledge regarding early detection of cancer cervix $(\mathrm{N}=168)$.

\begin{tabular}{|lccccc|}
\hline & N & Min. & Max. & Mean & $\begin{array}{l}\text { Std. } \\
\text { Deviation }\end{array}$ \\
\hline $\begin{array}{l}\text { Pre- } \\
\text { total }\end{array}$ & 168 & 9.00 & 29.00 & 21.6786 & 3.01756 \\
\hline $\begin{array}{l}\text { Post- } \\
\text { total }\end{array}$ & 168 & 13.00 & 30.00 & 23.2619 & 2.21654 \\
\hline
\end{tabular}

The comparison of pre-test and post-test level of knowledge shows that, the pre-test mean score 21.6 with standard deviation of 3.01 with minimum score was 9 and maximum score was 29 and the post-test mean score was 23.2 with standard deviation of 2.21 with minimum score was 13 and maximum score was 30 .

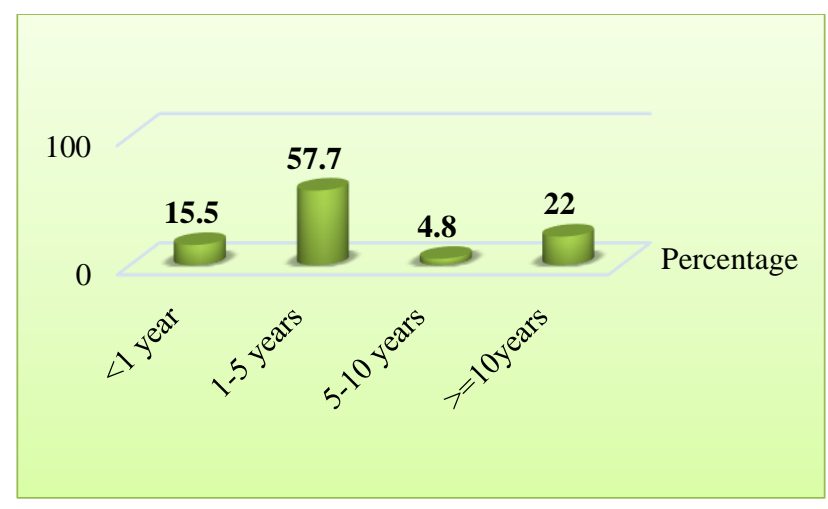

Figure 1: Distribution of the nurses in relation to their year of work experience.

The ' $t$ ' value was which showed $t=6.222$ and is significant at $\mathrm{P}<0.001$ level. The analysis revealed that, the post-test level of knowledge is higher than the pre-test level of knowledge. The calculated value was 6.222, which highly significant at $\mathrm{p}<0.05$ level.

Table 2: Scores of nurses regarding knowledge on early detection of cervical cancer.

\begin{tabular}{|lllll|}
\hline Scores & \multicolumn{2}{l}{ Pretest } & \multicolumn{2}{l|}{ Post test } \\
\hline $\begin{array}{l}\text { Good } \\
(\geq 24)\end{array}$ & 51 & 30.3 & 78 & 46.42 \\
\hline $\begin{array}{l}\text { Average } \\
(20-23)\end{array}$ & 85 & 50.5 & 81 & 48.21 \\
\hline $\begin{array}{l}\text { Poor } \\
(<=19)\end{array}$ & 32 & 19 & 9 & 5.35 \\
\hline
\end{tabular}

In Table 2 it can be observed that, Pre-test teaching 32 (19\%) subjects scored in the poor of range $\leq 19,85$ (50.5\%) subjects scored in the average range of 20-23 and $51(30.3 \%)$ samples scored in the good range of 24 and above comparing the result with post test scores the data shows that $9(5.35 \%)$ subject scored in the poor of range $\leq 19,81(48.2 \%)$ samples scored in the average range of $20-23$ and that $78(46.4 \%)$ samples scored in the range of 24 and above.

In the view of above it can be noted that all the subjects showed an increase in the post-test scores, it could be stated that gained knowledge through planned health education when compared to pre-test and post-test mean scores, which shows that planned health education was effective.

Table 3: Association of Pre-test post-test mean score with nurses' year of work experience.

\begin{tabular}{|lllll|}
\hline Work experience & $\begin{array}{l}\text { Pre- } \\
\text { total }\end{array}$ & $\begin{array}{l}\text { Post } \\
\text { total }\end{array}$ & $\begin{array}{l}\text { Paired } t \\
\text { test value } \\
\text { P value }\end{array}$ \\
\hline \multirow{2}{*}{$<1$ year } & Mean & 20.1154 & 23.5769 & 4.060 \\
\cline { 2 - 5 } & SD & 3.53640 & 2.23021 & $*<0.001$ \\
\hline \multirow{2}{*}{$1-5$ years } & Mean & 21.4124 & 23.0000 & 4.885 \\
\cline { 2 - 5 } & SD & 2.91459 & 2.36731 & $*<0.001$ \\
\hline \multirow{2}{*}{$5-10$ years } & Mean & 22.6250 & 24.2500 & 1.757 \\
\cline { 2 - 5 }$\geq 10$ years & SD & 1.68502 & 1.98206 & 0.122 \\
\cline { 2 - 5 } & Mean & 23.2432 & 23.5135 & 0.754 \\
\hline \multirow{2}{*}{ ANOVA } & F value & 2.38520 & 1.75787 & 0.456 \\
\cline { 2 - 5 } & P value & $<0.001$ & 0.269 & \\
\hline
\end{tabular}

ANOVA test was used to check whether there is effect of pre-test and post-test mean knowledge with year of work experiences. Irrespective of pre-test scores of nurses with duration of work experience, post test scores were similar and significant improvement was seen in nurses with less than 5 years' experience in post test scores. The study concluded that planned health education was effective by improving nurses' knowledge regarding cervix cancer. Hence the hypothesis of the study was accepted.

Table 4: Association of pre-test and post-tests mean score with nurses' qualification.

\begin{tabular}{|lllll|}
\hline \multirow{2}{*}{ Qualification } & $\begin{array}{l}\text { Pre- } \\
\text { total }\end{array}$ & $\begin{array}{l}\text { Post- } \\
\text { total }\end{array}$ & $\begin{array}{l}\text { Paired t } \\
\text { test value } \\
\text { P value }\end{array}$ \\
\hline \multirow{2}{*}{ ANM } & Mean & 22.7000 & 23.2000 & 0.406 \\
\cline { 2 - 5 } & SD & 2.94581 & 1.61933 & 0.694 \\
\hline \multirow{2}{*}{ GNM } & Mean & 22.4583 & 23.6667 & 3.713 \\
\cline { 2 - 5 } & SD & 2.87243 & 2.11594 & $*<0.001$ \\
\hline \multirow{2}{*}{ BSc } & Mean & 19.8636 & 22.6136 & 5.072 \\
\hline \multirow{2}{*}{ Pb.BSc } & SD & 2.99294 & 2.48919 & $*<0.001$ \\
\hline \multirow{2}{*}{ ANOVA } & Mean & 21.3333 & 22.7222 & 2.616 \\
\hline & SD & 1.84710 & 1.96456 & 0.018 \\
\hline & F value & 9.042 & 2.765 & \\
\hline & P value & $<0.001$ & 0.044 & \\
\hline
\end{tabular}

ANOVA test was used to check whether there is effect of pre-test and post-test mean knowledge with nurses' qualification. To find out the significance between the 
pre-and post-test knowledge score with qualification, the paired ' $t$ ' test was used. It was found that there is significant difference in the scores of GNM and BSc with ' $\mathrm{t}$ ' value 3.713 and 5.072 with $\mathrm{P}<0.001$. All nurses showed significant improvement except ANMs. Who had highest pre-test score among all categories of nursing staff.

Table 5: Association of pre-test and post-test mean score with marital status.

\begin{tabular}{|lllll|}
\hline \multirow{2}{*}{ Marital status } & \multicolumn{1}{c}{$\begin{array}{l}\text { Pre- } \\
\text { total }\end{array}$} & $\begin{array}{l}\text { Post- } \\
\text { total }\end{array}$ & $\begin{array}{l}\text { Paired } \mathrm{t} \\
\text { test value } \\
\text { P value }\end{array}$ \\
\hline \multirow{2}{*}{$\mathrm{M}$} & Mean & 22.2990 & 23.1031 & 2.494 \\
\cline { 2 - 5 } & SD & 2.83639 & 2.13836 & 0.014 \\
\hline \multirow{2}{*}{$\mathrm{U}$} & Mean & 20.8310 & 23.4789 & 7.055 \\
\hline \multirow{2}{*}{$\begin{array}{l}\text { Unpaired } \\
\text { t test }\end{array}$} & $\begin{array}{l}\mathrm{T} \\
\text { value }\end{array}$ & 3.200 & 1.086 & \\
\cline { 2 - 5 } & P value & 0.002 & 0.279 & \\
\hline
\end{tabular}

Unpaired t test was used to check whether there is effect of pre-test and post-test mean knowledge with marital status. It was found that, in pre-test mean knowledge, married subjects had more knowledge about cervical cancer as compared with unmarried. In post-test mean knowledge, it was found that the scores were similar.

To find out the significance between the pre-and post-test knowledge score, the paired ' $t$ ' test was used. It was found that there is significant difference in the scores of unmarried subjects of $\mathrm{t}=2.494$ with $\mathrm{P}<0.001$.

\section{DISCUSSION}

Findings of the study shows that there is significant improvement in knowledge of early detection of cancer cervix after imparting planned health education. The $t$ ' value showed $\mathrm{t}=6.222$ and is significant at $\mathrm{P}<0.001$ level. The analysis revealed that, the post-test level of knowledge is higher than the pre-test level of knowledge. The calculated value was 6.222 , which is highly significant at $\mathrm{P}<0.05$ level. This indicated the planned health education was effective method.

In a study done by Thavamani $\mathrm{K}$, et al to assess the existing level of knowledge, and to determine the effectiveness of structured teaching programme on cancer cervix among women residing at Ayanavaram health post. ${ }^{6}$ The study results showed that, the structured teaching programme was effective in increasing the knowledge at the level of $\mathrm{P}<0.001$. When comparing the result of this study, present study also revealed that, the post-test level of knowledge is higher than the pre-test level of knowledge. There is need for more education, awareness programme on cervical cancer, HPV infection and HPV vaccination for the women, students and nurses via school teaching and other media.

Study done by Mali NR et al to assess the effectiveness of structured education on knowledge regarding prevention of cervical cancer among ANM students. ${ }^{7}$ The finding of the study shows that ANM student nurses knowledge regarding prevention of cervical cancer was inadequate thus structured education helps to enhance the knowledge of ANM student nurses. In present study, the analysis revealed that all the subjects showed an increase in the post-test scores. It could be stated that gained knowledge through planned health education and found that Effectiveness of a planned education in terms of gain in knowledge regarding prevention, early detection of cervical cancer of subjects and but age, designation did not influence their knowledge, but the level of education was found positively influenced.

Harsha HN and Shubham conducted questionnaire based cross-sectional study on knowledge and screening for cervical cancer among women in Mangalore city. A sample size of 83 was calculated. A semi-structured questionnaire was developed. Majority of the women had poor knowledge about cervical cancer (81.9\% [68/83]) and it's screening (85.5\% [71/83]). Only 6 out of 83 women had undergone screening comparing result with present study, in pre-test majority of the nurses had average range of knowledge about cervical cancer 85 $(50.5 \%)$ and planned education teaching help to increase their knowledge significantly. ${ }^{8}$ Both studies highlights the need for educational programs regarding HPV infection and its complications such as cervical cancer.

Another study by Sneha BD et al, a cross-sectional interview based study was done among 200 nurses on "Knowledge and awareness of cervical cancer and its prevention among nursing staff of a tertiary care teaching institute in South India." Among all participated nurses, $85 \%(n=170)$ were aware of the term cancer cervix and $45 \%$ reported that it is the most frequent gynecological cancer in India. Only $30.6 \%$ reported that it is the leading cause of death among women due to cancer. None of the participants knew about the VIA method of screening for cervical cancer. Among 119 of those participants who knew that cervical cancer can be detected by Pap smear, only $5(4 \%)$ had ever undergone Pap smear examination. ${ }^{9}$ When comparing the result of supporting study with present study pre-test teaching $32(19 \%)$ subjects scored in the poor of range $\leq 19,85(50.5 \%)$ subjects scored in the average range of 20-23 and51(30.3\%) samples scored in the good range of 24 and above comparing the result with posttest scores the data shows that $9(5.35 \%)$ subject scored in the poor of range $\leq 19,81(48.2 \%)$ samples scored in the average range of $20-23$ and that $78(46.4 \%)$ samples scored in the range of 24 and above both the studies shows nurses identify certain aspects of cervical cancer correctly but their knowledge is not adequate, hence necessary changes should be made in their curriculum A similar study was conducted by Singh E et 
al on awareness of cervical cancer screening among nursing staff in a tertiary institution of rural India. Structured self-administered questionnaire based survey was done on 205 staff nurses was used. Result shows that $74 \%$ knew that Pap smear is used for detection of cervical cancer, but only 59\% knew that it can detect both cancerous as well as precancerous lesions of the cervix. Most nurses (79\%) thought that a speculum examination and Pap smear are procedures to be performed by the doctors. Among all the respondents, only $11 \%$ had ever undergone a Pap smear on themselves. ${ }^{10}$ Comparing result with present study after planned health education subjects scores significantly increase from poor to average and average to good with $\mathrm{P}<0.001$.

This study highlights that majority of nurses are not adequately equipped with knowledge concerning cervical cancer and studies prove that effectiveness of a planned education in terms of gain in knowledge on the prevention, early detection and awareness of cervical cancer of subjects. The study was limited to only available Nurses. No attempt is made to compare and correlate the other parameters

\section{CONCLUSION}

It is seen that training of nurses less than 30 years, with lesser experience than 5 years and with unmarried status benefited most. This may be suggestive of even lack of awareness and screening practices among young unmarried women. In service training at the time of entrance is recommended so that they can motivate the symptomatic and asymptomatic women attending hospital for any purpose. This passive screening of women more than 30 years will go a long way in down staging of cancer cervix in women attending hospitals for their own illness, illness of relatives, or coming to hospital for visiting someone admitted in the hospital.

\section{Recommendations}

Keeping in view the findings of the present study, the following recommendations were made.

- A similar study can be replicated in different setting with large scale to strengthen the findings

- The same study can be replicated to assess the various aspects of knowledge, awareness and practices regarding cervical cancer and prevention among nursing staff

- The study can be done to find out the barriers for not undergoing screening and acceptance for screening and also regarding awareness of vaccine. Study should be done frequently in the nurses to keep them alert and aware with advance inputs of topic to upgrade their knowledge.

\section{ACKNOWLEDGMENTS}

The Author is thankful to administrative authority of K.I.M.S.D.U. Karad and Nursing faculty for cooperation and support.

\section{Funding: No funding sources}

Conflict of interest: None declared

Ethical approval: The study was approved by the Institutional Ethics Committee

\section{REFERENCES}

1. Cervical cancer. Available
https://en.wikipedia.org/wiki/Cervical_cancer. Accessed 12 September 2016.

2. Human papillomavirus and related diseases, summary report 2017. Availble at http://www.hpvcentre.net/statistics/reports/XWX.pdf Accessed 25 September 2017.

3. Sreedevi A, Javed R, Dinesh A. Epidemiology of cervical cancer with special focus on India. Int $\mathbf{J}$ Womens Health. 2015;7:405-14.

4. WHO. Early detection of cancer. Available at http://www.who.int/cancer/detection/en/.accessed on 23 September 2017.

5. Cervical cancer early detection, diagnosis, and staging. Available at https://www.cancer.org/cancer/cervicalcancer/detection-diagnosis-staging.html. Accessed 23 September 2017.

6. Thavamani K, Susila C. Prevention and early detection of cervix cancer. Int J Curr Microbiol App Sci. 2015;4(8):283-7.

7. Nootan RM, Ramling M. Effect of structured education on knowledge regarding prevention of cervical cancer among ANM students. Int J Sci Res (IJSR). 2014;3(3):610-6.

8. Harsha HN, Shubham T. A study on knowledge and screening for cervical cancer among women in Mangalore city. Ann Med Health Sci Res. 2014;4(5):751-6.

9. Dhodapkar SB, Chauhan RC, Thampy S. Knowledge and awareness of cervical cancer and its prevention among nursing staff of a tertiary care teaching institute in South India. Int J Reprod Contracept Obstet Gynecol. 2014;3(4):1056-60.

10. Singh E, Seth S, Rani V, Dhiraj KS. Awareness of cervical cancer screening among nursing staff in a tertiary institution of rural India. J Gynecol Oncol. 2012;23(3):141-6.

Cite this article as: Tata S, Joshi R, Pratinidhi A, Vhaval V, Philip SE, Mulla RI, Kakade S.

Effectiveness of planned health education on knowledge of nurses working at tertiary care hospital regarding early detection of cancer cervix Karad, Western Maharashtra, India. Int J Reprod Contracept Obstet Gynecol 2018;7:173-7. 